\title{
Experiences of Healthcare Worker Returnees in Their Home Countries: A Scoping Review
}

\author{
Ferry Efendi (1D' \\ Lisa McKenna $\mathbb{D D}^{2}$ \\ Sonia Reisenhofer ${ }^{2}$ \\ Anna Kurniati $\mathbb{D D}^{3}$ \\ Eka Misbhahatul Marah Has' \\ 'Department of Advanced Nursing Care, \\ Faculty of Nursing, Universitas Airlangga, \\ Surabaya, Indonesia; ${ }^{2}$ School of Nursing \\ and Midwifery, La Trobe University, \\ Melbourne, Australia; ${ }^{3}$ Center of Planning \\ and Management of Human Resources \\ for Health, Ministry of Health of the \\ Republic of Indonesia, Jakarta, Indonesia
}

Correspondence: Ferry Efendi Department of Advanced Nursing Care, Faculty of Nursing, Universitas Airlangga, Jl. Mulyorejo Kampus C Unair, Surabaya, 60115 , Indonesia

Tel +62-3I59I3257; +628I33I533805

Email ferry-e@fkp.unair.ac.id
Background: International migration of healthcare workers is a global phenomenon driven by growing demand in developed countries and expectations of healthcare workers from developing countries to have improved employment and lives. This migration has been understood to impact both the individuals and countries involved, with positive and negative consequences. However, little is known about returnees' experiences that could be used to address challenges and optimize benefits. The aim of this review was to understand what is known about experiences of migrant health workers after returning to their home countries. Methods: A scoping review of primary research addressing experiences of migrant health workers upon their return to their homelands. A range of database were searched including Career and Technical Education Database via ProQuest, Cumulative Index to Nursing and Allied Health Literature (CINAHL), Education database via ProQuest, Excerpta Medica Care (EMCare) via Ovid, Education Resources Information Center (ERIC), Excerpta Medica database (EMBASE) via Ovid, MEDLINE and Scopus. A systematic process was performed guided by the work of Arksey and O'Malley. Eight databases were searched and 226 articles were retrieved. After screening articles and abstracts, 15 full-texts were assessed for eligibility, and finally seven studies were further analyzed and synthesized.

Results: Five qualitative studies, one quantitative study and one mixed methods study met inclusion criteria. Five themes emerged: (1) reasons to return, (2) upskilling and deskilling, (3) impact on human, financial, and social capital, (4) challenges and opportunities in the home country, and (5) facilitation supports.

Conclusion: Return migration is portrayed as a complex situation experienced by returnees. Structured policy and supports are required to help healthcare worker returnees prepare, and to adjust to life after their return. This study highlights the importance of comprehensive approach in return migration stage. Return migration policy should support healthcare worker returnees in their home country and facilitate utilization of their skills. Multistakeholder partnerships are vital to develop platforms for helping and facilitating returnees in the reintegration process at their home countries.

Keywords: international migration, migrant worker, migration policy, nurse migration, return migration

\section{Introduction}

Globalization has enhanced growing movement of health professionals across countries. Worldwide, the current health workforce shortage has been estimated at almost seven million in 2013 and this is predicted to double by $2030 .{ }^{1}$ Health workforce deficits in some developed countries have attracted health workers from less developed countries to migrate and seek better employment and living opportunities. $^{2}$ Dependency on foreign health workers is common in some wealthy 
countries, particularly Organization for Economic Cooperation and Development (OECD) countries, which show significant numbers. ${ }^{3}$ High-income countries remain dependent on overseas supply to overcome health workforce shortages due to mismatches between high exit rates, especially from retirement, and low production rates of national health workforce. ${ }^{1}$ The OECD countries are predicted to remain heavily reliant on high demand for health workers due to ongoing severe shortages by $2030 .{ }^{4}$

Negative and positive impacts of health workforce migration for source countries are debatable. ${ }^{5}$ Brain drain and brain waste phenomena are inevitable, ${ }^{6}$ although source countries often enjoy financial contributions from remittances sent by migrant health workers. ${ }^{7}$ Developing countries, with their own severe shortages of health workers, are negatively affected by the mobility of health professionals to developed countries. ${ }^{8}$ Despite high expectations of the migrant health workforce to practice their professions in their destination countries, in reality, many health workers experience brain waste due to working at lower levels of employment. ${ }^{6}$ For example, Filipino nurses reportedly worked as domestic caregivers in Canada, and nurses from the Philippines and Indonesia worked as care workers in Japan. ${ }^{9,10}$

The brain waste phenomenon among migrant health workers involves a deskilling process due to unutilized or underutilized professional skills during their stays in destination countries. ${ }^{11}$ Overseas health workers are often exempted from clinical practices because of local or institutional resistance, different job positions, or restrictions from national professional licensure systems. ${ }^{11}$ Language barriers, unrecognized academic and professional credentials, lack of continuing professional education, and lack of professional networks in the destination country also contribute to brain waste. ${ }^{12}$ This phenomenon gains considerable attention when such migrant health workers return to their homelands permanently. Loss of nursing skills while working overseas can make it more complicated for migrant nurses to return to practice. ${ }^{13}$ As a consequence, some nurses also lose their registration status.

Such loss has not been adequately addressed by policymakers in both source and host countries, despite voluntary implementation of the World Health Organization's global code of practice for international recruitment of health personnel. ${ }^{14}$ The code on migration management encourages bilateral agreement to promote mutual benefits of both source and receiving countries, as well as to enhance capacity building in source countries and facilitate return migrants bringing back skills and experiences to their homelands. ${ }^{15}$ Well-managed brain circulation is believed to benefit source countries in advancing education programs of health professionals, health research, and the healthcare system. ${ }^{16}$ Despite this common belief, in reality, the brain circulation is complex as most health professionals might expect not to return home if they can secure the employment contract in developed countries. ${ }^{17}$

To date, only a few studies have explored the benefits and challenges faced by the majority of migrant health workers upon return to their home countries. ${ }^{13}$ A scoping review to incorporate any empirical evidence from studies of health workforce returnees was considered useful to help understand this context. It aimed to provide additional knowledge from migrants' perspectives on how to optimize benefits for individual returnees, as well as home countries by alleviating challenges.

This study, therefore, was aimed towards gaining an extensive overview, by exploring themes emerging from the literature, about experiences of migrant health workers after returning to their home countries.

\section{Methods}

This scoping review was undertaken according to the guidelines for scoping review developed by Arksey and O'Malley (2005) and Levac, Colquhoun, and O'Brien (2010). ${ }^{18,19}$ A scoping review allowed scrutiny of all relevant evidence on the particular issue without considering individual study designs, while ensuring a systematic and rigorous process. ${ }^{19}$ This was essential for return migration issues due to the potential for few studies having investigated experiences of returnees after migrating back to their home countries.

\section{Step One: Research Question}

The review was guided by the following research question: "What are the experiences of healthcare worker returnees in their home countries?"

\section{Step Two: Identification of Relevant Studies}

This study employed a three-step search strategy, according to Joanna Briggs Institute (JBI) scoping review guidelines. ${ }^{20}$ The initial step was a limited search in Scopus, PubMed and ProQuest conducted in September 2019. We then analyzed text for words contained in titles and abstracts of retrieved papers to specify appropriate key terms. Several relevant terms (eg, "return migration", "returnees", "return migrant", 
"return emigrant", "return immigrant", "return skilled migrants", "return diaspora" AND "health professional", "nurse", "doctor", "midwife", "healthcare worker", "dentist", "pharmacist", "public health specialist) were identified accordingly.

The next step, the primary search was undertaken in October 2019 using eight databases: Career and Technical Education Database via ProQuest, Cumulative Index to Nursing and Allied Health Literature (CINAHL) via EBSCO, Education database via ProQuest, Excerpta Medica Care (EMCare) via Ovid, Education Resources Information Center (ERIC), Excerpta Medica database (EMBASE) via Ovid, MEDLINE and Scopus. Combinations and variations from the previous search were included with specific search strings. The search did not limit year of published papers and only included English language literature. Finally, reference records of all recognized articles and reports were manually searched to find additional studies. The search process was established by the research team and carried out by the librarian and authors. Two authors reviewed the search output and extracted data. A third investigator managed conflicts.

\section{Step Three: Selection of Studies and Data Management Process}

Papers were included based on the following criteria: (i) primary studies focused on returning health professionals; and (ii) primary studies focused on experiences of health professionals in their home countries. We defined returning health professionals as including the movement of any type of health professional to their home countries after working as health professionals in other countries.

Exclusion criteria were applied for papers with at least one of the following indications: (i) published in language other than English; (ii) non-research-based publications, such as commentaries, opinions, correspondence, book reviews, conference abstracts, analysis of secondary data, tutorials, concept analyses, or policy documents; and (iii) not focused on actual return or intention to return migrate.

A total of 226 citations were retrieved from eight databases: Scopus (27 citations), Career \& Technical Education Database (41 citations), CINAHL ( 7 citations), Education database (90 citations), EMCare (5 citations), EMBASE (19 citations), ERIC (20 citations), and MEDLINE (17 citations). Following removal of 31 duplicates, titles and abstracts of 151 studies were scrutinized to discard irrelevant papers. As a result, 136 studies were excluded, leaving 15 for full-text review. Seven studies were included in the final review (see Figure 1). Two reviewers individually undertook each stage and any emerging discrepancies were discussed.

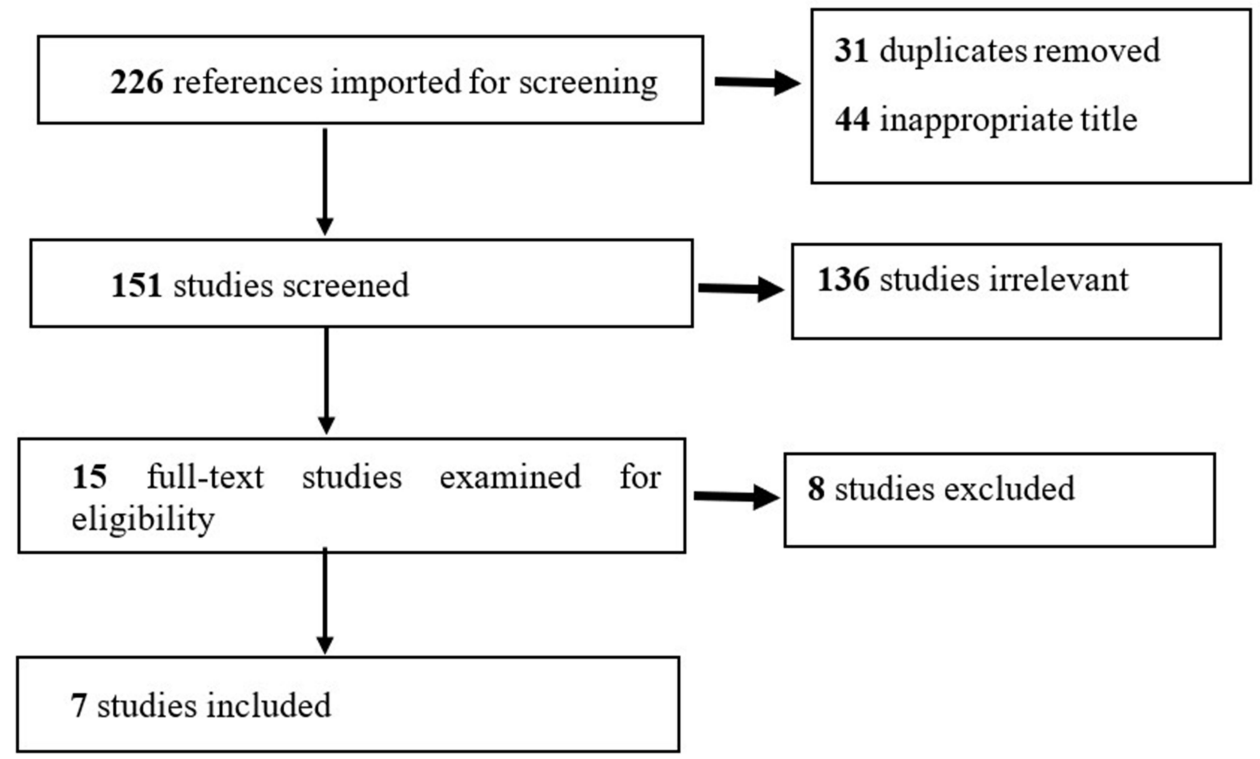

Figure I PRISMA diagram.

Note: Adapted from Tricco AC, Lillie E, Zarin W, O'Brien KK, Colquhoun H, Levac D, Moher D, Peters MDJ, Horsley T, Weeks L, Hempel S, Akl EA, Chang C, McGowan J, Stewart L, Hartling L, Aldcroft A, Wilson MG, Garritty C, Lewin S, Godfrey CM, Macdonald MT, Langlois EV, Soares-Weiser K, Moriarty J, Clifford T, Tunçalp Ö, Straus SE. PRISMA Extension for Scoping Reviews (PRISMA-ScR): Checklist and Explanation. Ann Intern Med. 2018. PMID: 30I78033. Creative Commons license and disclaimer available from: http://creativecommons.org/licenses/by/4.0/legalcode. ${ }^{34}$ 
A third reviewer managed any conflicts. After the abstract screening and assessing the full text, seven articles were considered relevant to be included in the analysis (Figure 1).

\section{Step Four: Charting the Data}

In this stage, we extracted data from the seven included studies into a table with the headings: author-source country-destination country, study aim, study design, participants and sample size, key findings and limitations. This stage was important to map the data format and extract data.

\section{Step Five: Collating, Summarizing and Reporting Results}

In this stage, we used Excel to organize extracted data and assist in coding into different themes. Thematic analysis was used and helped to identify, analyze and narrate patterns emerging. ${ }^{19}$

\section{Results}

A total of seven papers from 15 studies were included: five qualitative, one quantitative and one mixed methods. These were based on work carried out in five different countries of worker origin: Jamaica, Indonesia, Ghana, Nigeria and Botswana. When viewed according to economic income level of source countries, the majority were from middle to lower income countries. The middle and upper economic income countries included Jamaica, and Botswana, and middle to lower economic income countries were Ghana and Nigeria, while Indonesia was an upper middle income country. ${ }^{21}$ With regard to study design, there were five qualitative, one mixed methods, and one quantitative studies. Results of all the papers reflected return migration experiences among returnees (Table 1) while the identified themes as depicted in Table 2.

\section{Reasons to Return}

Decisions to return among migrant health workers included personal reasons such as family issues, nationalism, feeling stressed/under pressure at work, motivation to contribute to the national health system and economic motives. ${ }^{13,22}$ Family considerations such as marriage, taking care of children and elderly parents, parental or spousal consent, and building personal or family businesses were among reasons driving migrant health workers decided to return home. ${ }^{2,13,23}$ The desire to have direct participation in the national development and make a professional contribution to the national healthcare system led migrant health care workers to return to their countries of origin. ${ }^{13,22}$ Lack of work-life balance reportedly pushed Indonesian migrant care workers in Japan to head back to their home country. ${ }^{13}$

Other reasons related to external factors driving return migration of health workers included failing the professional examination, goal accomplishment, end of employment contract, racial discrimination, retirement, language and communication difficulties, and having engaged in more appropriate works. ${ }^{2,13,22,24}$

\section{Upskilling and Deskilling}

One key message emerging from the review was concern over knowledge and skills improving or worsening. Pros and cons were discussed in various contexts as issues for return migration regarding individuals' knowledge and skills. Returnees to Indonesia discussed that after returning home, health workers expected to contribute to the national health development by utilizing the knowledge and skills acquired overseas. ${ }^{13}$ A study by Motlhatlhedi and Nkomazana (2018) described knowledge and skills gained while working in developed countries could bring advantages to the health systems of developing countries. ${ }^{2}$ Such benefit was expected if the health professional returned to their country of origin and professional practice, even if for short periods.

Some health professional returnees reportedly brought home additional clinical and instrumentation skills from abroad such as in vitro fertilization, dialysis, and other health-related techniques. Mostly, they received medical or nursing skills, compared to skills in training and management. ${ }^{22}$ Brown (1996) estimated that $76 \%$ of postmigrant nurses in Jamaica had returned to clinical practice and most returned to nursing practice in public sector areas. $^{25}$

In Indonesia, around $50 \%$ of the Indonesia Japan Economic Partnership (IJEPA) nurses in Japan returned to their country of origin because they did not pass the certification examination there, either as nurses or caregivers during their working contracts. ${ }^{24}$ For nurse returnees who previously engaged in non-nursing positions in their destination country, reduced opportunities to perform nursing care decreased their abilities. ${ }^{13}$ As a result, returnees had no capacity to transfer skills and knowledge they had acquired abroad. ${ }^{26}$ 
Table I Summary of Included Studies

\begin{tabular}{|c|c|c|c|c|c|}
\hline $\begin{array}{l}\text { Author, } \\
\text { Source } \\
\text { Country, } \\
\text { Destination } \\
\text { Country }\end{array}$ & Study Aim & Study Design & $\begin{array}{l}\text { Participants } \\
\text { \& Sample } \\
\text { Size }\end{array}$ & Key Findings & Limitations \\
\hline $\begin{array}{l}\text { Brown (1996) } \\
\text { Jamaica } \\
\text { United States }\end{array}$ & $\begin{array}{l}\text { To understand return } \\
\text { migration process among } \\
\text { Jamaican nurses }\end{array}$ & $\begin{array}{l}\text { Case study using } \\
\text { in-depth } \\
\text { interview }\end{array}$ & $\begin{array}{l}80 \text { registered } \\
\text { nurse } \\
\text { returnees }\end{array}$ & $\begin{array}{l}\text { Loss of qualified nurses, } \\
\text { especially investment in } \\
\text { nurses training but also } \\
\text { gained remittances, material } \\
\text { goods and skills. } \\
\text { Reasons to migrate } \\
\text { (financial and professional) } \\
\text { and motivations to return } \\
\text { (family), employment and } \\
\text { return to nursing practice, } \\
\text { financial benefit, } \\
\text { professional training, the } \\
\text { government policy support }\end{array}$ & $\begin{array}{l}\text { A small study involving only } \\
\text { nurses from two hospitals } \\
\text { in Jamaica }\end{array}$ \\
\hline $\begin{array}{l}\text { Efendi et al } \\
(20 \mid 3) \\
\text { Indonesia } \\
\text { Japan }\end{array}$ & $\begin{array}{l}\text { To investigate the challenges } \\
\text { and opportunities } \\
\text { experienced by nurse } \\
\text { returnees from Japan }\end{array}$ & $\begin{array}{l}\text { Self-report } \\
\text { survey and semi- } \\
\text { structured } \\
\text { interview. }\end{array}$ & $\begin{array}{l}20 \text { registered } \\
\text { nurses }\end{array}$ & $\begin{array}{l}\text { Challenges and difficulties of } \\
\text { return migration } \\
\text { particularly to find a job in } \\
\text { nursing area. }\end{array}$ & $\begin{array}{l}\text { Focused on nurse } \\
\text { returnees from the } \\
\text { Indonesia Japan Economic } \\
\text { Partnership (IJEPA) } \\
\text { program or bilateral } \\
\text { scheme. Not generalizable } \\
\text { to other populations }\end{array}$ \\
\hline $\begin{array}{l}\text { Adzei et al } \\
(20 \mid 4) \\
\text { Ghana } \\
\text { (United States } \\
\text { and United } \\
\text { Kingdom) }\end{array}$ & $\begin{array}{l}\text { To investigate the trend of } \\
\text { return migration of health } \\
\text { professionals, experience of } \\
\text { returnees and how it is } \\
\text { impacting the delivery of } \\
\text { health services in Ghana }\end{array}$ & $\begin{array}{l}\text { A qualitative } \\
\text { exploratory case } \\
\text { study, semi- } \\
\text { structured } \\
\text { interview. }\end{array}$ & $\begin{array}{l}\text { Health } \\
\text { professionals: } \\
25 \text { doctors, } 36 \\
\text { nurses }\end{array}$ & $\begin{array}{l}\text { Lack of support from host } \\
\text { and home countries. }\end{array}$ & $\begin{array}{l}\text { Did not mention specific } \\
\text { methodological orientation } \\
\text { underpinning the study }\end{array}$ \\
\hline $\begin{array}{l}\text { Nwadiuko, } \\
\text { James, } \\
\text { Switzer, and } \\
\text { Stern, (2016) } \\
\text { Nigerian } \\
\text { United States }\end{array}$ & $\begin{array}{l}\text { To assess the extent to } \\
\text { which immigrant physicians } \\
\text { may support health systems } \\
\text { and identify barriers }\end{array}$ & $\begin{array}{l}\text { Mixed methods, } \\
\text { questionnaire } \\
\text { and interview. }\end{array}$ & $\begin{array}{l}\text { I56 medical } \\
\text { doctors }\end{array}$ & $\begin{array}{l}\text { Potential contributions of } \\
\text { migrant doctors to } \\
\text { strengthen Nigeria health } \\
\text { system. }\end{array}$ & Potential selection bias \\
\hline $\begin{array}{l}\text { (Kurniati et al, } \\
\text { 20I7) } \\
\text { Indonesia } \\
\text { Japan }\end{array}$ & $\begin{array}{l}\text { To explore the journey of } \\
\text { becoming returnees }\end{array}$ & $\begin{array}{l}\text { Hermeneutic } \\
\text { phenomenology; } \\
\text { in-depth } \\
\text { interview }\end{array}$ & $\begin{array}{l}\text { I5 registered } \\
\text { nurse } \\
\text { returnees }\end{array}$ & $\begin{array}{l}\text { Deskilling and struggled to } \\
\text { re-enter the nursing } \\
\text { profession or to find other } \\
\text { non-nursing jobs were } \\
\text { reported. }\end{array}$ & $\begin{array}{l}\text { Interviewers were } \\
\text { unfamiliar with returnees, } \\
\text { which might have } \\
\text { prevented them from } \\
\text { speaking openly about their } \\
\text { conditions and opinions. } \\
\text { Participants were selected } \\
\text { from one region only. }\end{array}$ \\
\hline
\end{tabular}

(Continued) 
Table I (Continued).

\begin{tabular}{|c|c|c|c|c|c|}
\hline $\begin{array}{l}\text { Author, } \\
\text { Source } \\
\text { Country, } \\
\text { Destination } \\
\text { Country }\end{array}$ & Study Aim & Study Design & $\begin{array}{l}\text { Participants } \\
\text { \& Sample } \\
\text { Size }\end{array}$ & Key Findings & Limitations \\
\hline $\begin{array}{l}\text { Motlhatlhedi } \\
\& \\
\text { Nkomazana, } \\
\text { (20I8) } \\
\text { Botswana } \\
\text { (United } \\
\text { Kingdom, } \\
\text { United States } \\
\text { and Republic } \\
\text { of South } \\
\text { Africa) }\end{array}$ & $\begin{array}{l}\text { To investigate perspectives } \\
\text { of healthcare workers } \\
\text { returning to Botswana after } \\
\text { working in the diaspora }\end{array}$ & $\begin{array}{l}\text { Qualitative } \\
\text { approach; in- } \\
\text { depth interview }\end{array}$ & $\begin{array}{l}8 \text { health } \\
\text { personnel } \\
\text { (nurse, } \\
\text { medical } \\
\text { doctor and } \\
\text { rehabilitation } \\
\text { scientist) }\end{array}$ & $\begin{array}{l}\text { Difficulties in reintegration } \\
\text { phase while returning to the } \\
\text { home country }\end{array}$ & $\begin{array}{l}\text { Use of purposive sampling } \\
\text { strategy and small study } \\
\text { sample }\end{array}$ \\
\hline $\begin{array}{l}\text { Efendi F et al, } \\
(20 \mid 9) \\
\text { Indonesia } \\
\text { Japan }\end{array}$ & $\begin{array}{l}\text { To explore the situation of } \\
\text { return migration among } \\
\text { Indonesian nurses }\end{array}$ & $\begin{array}{l}\text { Descriptive } \\
\text { study, and } \\
\text { questionnaire }\end{array}$ & $\begin{array}{l}20 \text { Indonesian } \\
\text { nurse } \\
\text { returnees }\end{array}$ & $\begin{array}{l}\text { Returnee career situations } \\
\text { varies between working as } \\
\text { a nurse and non-nurse }\end{array}$ & $\begin{array}{l}\text { Data limited on returnees } \\
\text { under bilateral agreement }\end{array}$ \\
\hline
\end{tabular}

Migrant health workers who experience brain waste abroad might perceive losing knowledge and professional competency. ${ }^{13,25}$ For example, migrant nurses who work as caregivers might only be allowed to perform daily activities related to the basic needs of patients, such as feeding, bathing, and taking patients for walks. Despite having clinical competency in their home country, different job positions, and not being certified as professional nurses in the destination country, restricts nurses from practicing their nursing skills. The resulting loss of nursing skills leads to loss of confidence as a health practitioner once the nurse returns to their home country. ${ }^{13}$

\section{Impacts on Human, Financial, and Social Capital}

Some studies discussed benefits of return migration of nurses, such as in human capital gaining clinical skills and knowledge, ${ }^{2,22}$ financial, ${ }^{13,22,26}$ and social capital. $^{22,24,27,28}$ Gaining human and financial capital may contribute to improvements in the health sector of the home country. Some health professionals reported having acquired clinical skills from their work experience overseas such as in-vitro fertilization, hemodialysis, newborn congenital disorders, gastrointestinal surgery, hematology, pediatrics, obstetric care and anesthesia. ${ }^{2}$ Their newly acquired skills could benefit the health care facilities that subsequently employ those health professionals.

Benefits of financial capital were shown from the contribution of financial gain by returnees to the economic sector in their home country, such as through establishment of private businesses, pensions/remuneration/allowances, scholarship funding, and provision of diagnostic and/or medical education facilities. ${ }^{13,22,26}$ Change in better wealth and higher social status of individual or families of return health workers was also evident in Ghana. ${ }^{22}$

In terms of social capital, such benefits may include provision of social support to families and relatives, supports to charitable community organizations, helping others through creation of employment opportunities, cultural adaptation, and health system events in home countries, especially if the returnees were domestically trained. $^{22,24,27,28}$

\section{Challenges and Opportunities in the Home Country}

Across studies, various challenges faced by returnees were identified. Indonesian nurse returnees reported their biggest hurdle was in getting a job after returning home. It reportedly took some considerable time for some returnees to get hired. Others experienced lack of recognition toward 
Table 2 Themes Identified

\begin{tabular}{|c|c|c|}
\hline Themes & Detailed Aspects & Sources \\
\hline \multirow[t]{13}{*}{ Reason to return } & Family reasons & $\begin{array}{l}\text { (Adzei et al, 2014; Brown, 1996; Efendi et al, 2013; Kurniati et al, 2017; Motlhatlhedi \& } \\
\text { Nkomazana, 2018; Poppe et al, 2016) }\end{array}$ \\
\hline & Love of the country & (Brown, 1996; Kurniati et al, 2017; Motlhatlhedi \& Nkomazana, 2018) \\
\hline & Failed to pass the certification exam & (Brown, 1996; Efendi et al, 2013; Kurniati et al, 2017) \\
\hline & Feeling stress/underpressure & (Brown, 1996; Kurniati et al, 2017) \\
\hline & Accomplished goals & (Adzei et al, 20I4; Motlhatlhedi \& Nkomazana, 2018) \\
\hline & Accomplished working contract & (Brown, 1996; Efendi et al, 2013) \\
\hline & $\begin{array}{l}\text { Motivation to contribute to the health } \\
\text { system }\end{array}$ & (Adzei et al, 20I4) \\
\hline & Racial discrimination & (Adzei et al, 20I4) \\
\hline & Retirement & (Adzei et al, 20I4) \\
\hline & Pursuing a higher level of education & (Efendi et al, 2013) \\
\hline & Economic motive & (Efendi et al, 2013) \\
\hline & Language and communication barriers & (Kurniati et al, 20I7) \\
\hline & Engaged in a more proper job & (Kurniati et al, 2017) \\
\hline \multirow[t]{5}{*}{ Upskilling and deskilling } & Contribute to the health sector & (Brown, 1996; Motlhatlhedi \& Nkomazana, 2018; Poppe et al, 2016) \\
\hline & Additional skills & (Adzei et al, 2014; Brown, 1996) \\
\hline & Loss of professional skills & (Brown, 1996; Kurniati et al, 2017) \\
\hline & Lack of confidence as a health worker & (Brown, 1996; Kurniati et al, 2017) \\
\hline & $\begin{array}{l}\text { Inability to transfer skills and } \\
\text { knowledge }\end{array}$ & (Efendi et al, 2019) \\
\hline \multirow{11}{*}{$\begin{array}{l}\text { Impact on human, financial, and } \\
\text { social capital }\end{array}$} & Betterment of the health sector & (Adzei et al, 2014) \\
\hline & $\begin{array}{l}\text { Offer social support to family } \\
\text { relations }\end{array}$ & (Adzei et al, 2014) \\
\hline & Establish private business & (Adzei et al, 2014; Kurniati et al, 2017) \\
\hline & Occupy prestigious positions & (Adzei et al, 2014) \\
\hline & Pension/remuneration/allowance & (Efendi et al, 2019; Efendi et al, 2013) \\
\hline & Economy growth of the country & (Adzei et al, 20I4) \\
\hline & Provide scholarship funding & (Nwadiuko et al, 2016) \\
\hline & Reunited with family & (Adzei et al, 2014) \\
\hline & Join in a charitable organization & (Adzei et al, 2014) \\
\hline & $\begin{array}{l}\text { Language, cultural practices and health } \\
\text { systems realities }\end{array}$ & (Nwadiuko et al, 2016) \\
\hline & Social mobility & (Adzei et al, 2014) \\
\hline
\end{tabular}

(Continued) 
Table 2 (Continued).

\begin{tabular}{|c|c|c|}
\hline Themes & Detailed Aspects & Sources \\
\hline \multirow{7}{*}{$\begin{array}{l}\text { Challenges and opportunities in } \\
\text { the home country }\end{array}$} & Getting a job opportunity & (Kurniati et al, 2017) \\
\hline & Administrative barriers & (Adzei et al, 2014) \\
\hline & Bribery and corruption & (Adzei et al, 2014) \\
\hline & Area of expertise was not available & (Adzei et al, 2014) \\
\hline & Interpersonal challenges & (Adzei et al, 2014) \\
\hline & Institutional crisis, war, conflicts & (Poppe et al, 2016) \\
\hline & Unsupportive health system & (Motlhatlhedi \& Nkomazana, 2018) \\
\hline \multirow[t]{5}{*}{ Facilitation supports } & $\begin{array}{l}\text { Promote a brain circulation scheme, } \\
\text { job fair }\end{array}$ & (Efendi et al, 2013) \\
\hline & $\begin{array}{l}\text { The improved remuneration and the } \\
\text { standard of living }\end{array}$ & (Adzei et al, 2014) \\
\hline & $\begin{array}{l}\text { Upgrading medical device in health } \\
\text { facility }\end{array}$ & (Brown, 1996) \\
\hline & Improve their health care service & (Motlhathedi \& Nkomazana, 2018) \\
\hline & Support from government agencies & (Dustmann et al, 201 I; Nwadiuko et al, 2016) \\
\hline
\end{tabular}

their overseas work experience and were hired in similar positions as newly graduated employees. ${ }^{13}$

In Ghana, major challenges were considered to be institutional, indicated from the extent of governmental supports from both the source and receiving countries, as well as supports from the Ghanaian health system. ${ }^{22}$ Challenges expressed by health professional returnees included difficulties in readjusting to life and adapting with the current environment in Ghana after several years living abroad. Furthermore, there was reportedly inadequate government assistance to help facilitate those returnees through the reintegration process. ${ }^{22}$ Similar to Indonesian nurse returnees, ${ }^{13}$ Ghanaian returnees also reported tough process to enter the labor market. Returnees complained about bureaucratic constraints related to high import tariffs on medical and health devices for private businesses and incompetent personnel with lack of human relations skills at national health government agencies. Others encountered challenging situations due to low availability of certain areas of nursing expertise in Ghana. ${ }^{22}$

In a study by Brown (1996), a notable challenge in Jamaica was a popular notion that training health professionals in the Caribbean region was for export purposes, mainly to developed countries. ${ }^{25}$ This concept, therefore, challenged the development of health professionals whereby migration was a circular process that directly benefited the region on return home. In the United States, Nigerian-born physicians described that at their home country, the health system level posed obstacles when developing their health care system. However, they acknowledged that partnering with the government was essential for the diaspora to achieve expected health goals. ${ }^{27}$ For some migrant health workers in Belgium and Austria, willingness to return home was hampered by continual internal conflicts and wars in their home countries in Sub-Saharan Africa. ${ }^{28}$ In Botswana, there were reported health system challenges that made practicing in Botswana unattractive, such as feeling low appreciation from the government. ${ }^{2}$

\section{Facilitation Supports}

Returnees may expect facilitation support from governments. In Indonesia, the Ministry of Health $(\mathrm{MoH})$ encouraged a bilateral cooperation scheme to manage overseas employment for health workers. The $\mathrm{MoH}$ also promoted implementation of the concept of brain circulation in migration development of the health workforce. This strategy was expected to empower returning of health workers back to Indonesia, making contributions to the health system with their advanced knowledge and skills gained from their working experience abroad. ${ }^{14}$ While Indonesian nurse returnees of the IJEPA program expected to receive 
the privilege of being recruited as civil servants as part of the brain circulation scheme, this expectation was unlikely fulfilled due to civil servant policy of zero-growth and equal employment opportunity. A job fair facilitated by the $\mathrm{MoH}$ was regarded by IJEPA nurse returnees as a beneficial approach to enable them to be re-employed quickly and to obtain decent nursing employment. ${ }^{24}$ In Ghana, the government supported health personnel returnees with better remuneration, along with increased investments by the government and other stakeholders to improve working environments in the health sector. Generally, in comparison to socio-economic indicators, the standard of living in Ghana had improved over recent decades which might also attract them to return. ${ }^{22}$

In Jamaica, the government introduced efforts to improve the working conditions of nurses with improved equipment and infrastructure in public health facilities. The Jamaican Government prioritized nurses to receive government housing within the hospital area supported by a transportation service. They also offered nurses flexible working hours and employment contracts. ${ }^{25}$ US-based Nigerian physicians recognized the importance of engagement with their home country's healthcare system at various initiatives. The role of ethnic medical groups was valued as a useful collaborator for the diaspora in promoting contributions to health development in the home country. Partnerships with other organizations also allowed the diaspora to receive advice in contributing at a network level, and even on an individual basis. ${ }^{27}$ Engagement of migrant health workers to the national health development should be promoted and facilitated by the source countries. ${ }^{28}$ In Botswana, returning health workers found reintegration relatively easy with the national healthcare system, especially for migrant workers who were working in the private sector. ${ }^{2}$

\section{Discussion}

This scoping review sought to understand what is known about experiences of migrant health workers after returning to their home countries. There were various factors underpinning reasons to return, both at micro and macro levels. At a micro-level, the greatest motivation for migration was for financial reasons, as low remuneration limited abilities to fulfill needs such as buying houses, vehicles. ${ }^{22}$ In addition, migration became an option that could help them to earn sufficient money to start building private businesses. ${ }^{25}$ At the macro level, motivation was not fulfilling the professional needs of health workers such as career progression and job satisfaction, and poor working conditions. ${ }^{2,22,25}$ These were consistent with previous research conducted by Dohlman, Dimeglio, Hajj, and Laudanski (2019) that economic necessity became a dominant driver of physicians moving abroad. ${ }^{29}$ In addition, this study noted that factors related to self-actualization, such as professional development, were also strong contributors to the international mobility of health workers seeking opportunities for knowledge generation and training. The motivation of health workers to enhance professional competence is essential to build health systems that accommodate lifelong learning through professional development. ${ }^{30}$ On the other hand, important factors to push health workers back included family reasons (religious pilgrimage, marriage plan, parenting, safe living). ${ }^{24}$ Family factors became the principal consideration influencing health workers' decisions to return or not. ${ }^{2,22,31}$ Research conducted by Brown (1996) found that most nurses living abroad maintained contact with their families in Jamaica. ${ }^{25}$ Visiting the family for reunions and providing financial support were reported reasons they returned, temporarily or permanently.

Increasing or decreasing knowledge and expertise skills are key issues for health workforce migration. A range of knowledge and skills issues impacting on enhancement or deterioration were identified through the studies reviewed. The return of health professionals could significantly contribute to the health sector through knowledge transfer. ${ }^{2,28}$ Although health professionals might return only for a short time, they still can provide potential benefits. A few studies mentioned that returnees applied their medical skills, such as certain clinical skills, to support the advancement of medical practice in hospitals in their home countries. ${ }^{2,22}$ On the other side, skills deterioration and difficulty to transfer returnees' skills required further investigations. ${ }^{13,26}$

Successful international migration of the health workforce brings positive impact in reinforcement in human, financial, and social capital. ${ }^{32}$ The health professional can acquire various skills through training or practice in health care services while working in developed countries. The financial capital focuses on monetary income that can be utilized in improving the family's economic status or initiating a business. ${ }^{13,22}$ It was common for migrant doctors and nurses in another study to use savings and remittances from their work abroad to establish and run their own businesses upon returning to their home countries, ${ }^{33}$ while social capital enjoyed by returnees included willingness to support charitable organizations helping people in the community. ${ }^{22}$ Returning to one's home country was believed by some health workers to be the best decision to make a real professional contribution to their motherland and strengthen family relations. ${ }^{22}$ 
Challenges in the home country were identified across studies in this review. Indonesian nurse returnees dealt with various challenges, especially with one of the hardest being getting employed again. ${ }^{13}$ This challenge was caused by differences in job situations between advanced and developing countries. This condition had not been anticipated by returnees leading to frustration in finding new employment as their overseas working experience was disregarded and they were unable to increase their chances of landing respectable positions in their home countries. A study about challenges of return migration from a developed country to Ghana conducted by Adzei et al (2014) identified that most health workers migrating experienced administrative problems, such as application letters getting misplaced. ${ }^{22}$ Kurniati et al (2017) offered several recommendations on strategies to address such challenges for returnees before they returned, such as restoring competency and training of those who stayed in the profession, building positive character (good person, helpful, respectful, and honest), processing language proficiency, saving money to build private businesses, and assistance from the government. ${ }^{13}$

This review has shown that returnees can experience support from governments. The Government of Indonesia under the Ministry of Health attempted to optimize the benefits of a bilateral cooperation scheme with Japan that enabled facilitating the migration process before departure, during overseas employment and return migration. ${ }^{24}$ Such a return would be more attractive for migrant health workers when the government assures improved remuneration, better working environments were in place and the public and private sectors continue to increase investment in the health sector, as exemplified in Ghana, Botswana and Jamaica. ${ }^{2,22,25}$ Making contributions to health development should be facilitated by governments of source countries to maintain engagement of migrant health workers with their healthcare system, including hospitals or other health entities which might also help when preparing to return..$^{27,28}$

This study highlights the importance of addressing return migration stage as a major component of managing international health workforce migration. The experience of healthcare worker returnees in the country of origin reflected that this phenomenon is complex and dynamic. Policymakers can use the results from this scoping review for establishing policies that tailor reintegration facilitation to the needs of health worker returnees. Collaborative partnership is needed particularly in facilitating knowledge and skill transfer of returnees to the strengthening of source countries' health systems. Mitigation of the profound consequences on return migration toward countries of origin and healthcare worker returnees should be established as a part of best practices.

\section{Limitations}

This scoping review included published studies only, and in English language only. Most studies recruited nurses, doctor and midwives; hence, it has not captured the return migration phenomenon of other types of health workers that might be different.

\section{Conclusion}

The experiences of returning healthcare workers varied across studies, including reasons to return, issues related to knowledge and skills, benefits of human-financial-social capital, challenges in home countries, and facilitation support. These phenomena suggest that life after working in overseas countries can be complex and multifaceted. The challenges and current situations of returnees need structured policies from governments and professional associations. Health care worker returnees should be able to cope and prepare for the future in their home countries, regardless of the existence of supporting policies.

\section{Author Contributions}

All authors contributed to data analysis, drafting or revising the article, have agreed on the journal to which the article will be submitted, gave final approval of the version to be published, and agree to be accountable for all aspects of the work.

\section{Funding}

This study was funded by Universitas Airlangga, Surabaya, Indonesia through "Article Review Program" Scheme (Grant number 942/UN3.14/LT/2019). An ethical approval is not needed in a scoping review.

\section{Disclosure}

The authors report no conflicts of interest in this work.

\section{References}

1. Liu JX, Goryakin Y, Maeda A, Bruckner T, Scheffler R. Global health workforce labor market projections for 2030. Hum Resour Health. 2017;15(1):1-12. doi:10.1186/s12960-017-0187-2

2. Motlhatlhedi K, Nkomazana O. Home is home-Botswana's return migrant health workers. PLoS One. 2018;13(11):1-16. doi:10.1371/ journal.pone.0206969

3. OECD. Recent Trends in International Migration of Doctors, Nurses and Medical Students. OECD Publishing; 2019.

4. Scheffler RM, Arnold DR. Projecting shortages and surpluses of doctors and nurses in the OECD: what looms ahead. Heal Econ Policy Law. 2019;14(2):274-290. doi:10.1017/S174413311700055X 
5. IOM. World Migration Report 2020. International Organization for Migration; 2020.

6. World Health Organization. The brain drain to brain gain- supporting the WHO Code of Practice on the recruitment of health personnel; 2018. Available from: https://www.who.int/workforcealliance/braindrain-brain-gain/en/. Accessed May 2, 2021.

7. Efendi F, Kurniati A, Savage E, Nursalam N, Yusuf A, Kusnanto K. Return migration of nurses: a concept analysis. Indian J Public Heal Res Dev. 2018;9(9):199. doi:10.5958/0976-5506.2018.00994.4

8. World Health Organization.State of the World's Nursing 2020: Investing in Education, Jobs and Leadership. World Health Organisation; 2020. https://www.paho.org/es/documentos/situacionenfermeria-mundo-2020-resumen-orientacion. Accessed August 5, 2021.

9. Asis E, Carandang RR. The plight of migrant care workers in Japan: a qualitative study of their stressors on caregiving. $J$ Migr Heal. 2020;1:100001. doi:10.1016/j.jmh.2020.100001

10. Salami B. Migrant nurses and federal caregiver programs in Canada: migration and health human resources paradox. Can J Nurs Res. 2016;48(2):35-40. doi:10.1177/0844562116663951

11. Bludau H. Global healthcare worker migration. In: Oxford Research Encyclopedia of Anthropology. Oxford University Press; 2021. doi10.1093/acrefore/9780190854584.013.231

12. Korzeniewska L, Erdal MB. Deskilling unpacked: comparing Filipino and Polish migrant nurses' professional experiences in Norway. Migr Stud. 2021;9(1):1-20. doi:10.1093/migration/mnz053

13. Kurniati A, Chen C-M, Efendi F, Ogawa R. A deskilling and challenging journey: the lived experience of Indonesian nurse returnees. Int Nurs Rev. 2017;64(4):494-501. doi:10.1111/inr.12352

14. Efendi F, Mackey T, Huang M-C, Chen C. IJEPA: gray area for health policy and international nurse migration. Nurs Ethics. 2017;24(3):313-328. doi:10.1177/0969733015602052

15. Yeates N, Pillinger J. International Health Worker Migration and Recruitment: Global Governance, Politics and Policy. Routledge; 2019.

16. Majeed MH, Ali AA, Saeed F. International medical graduates: from brain drain to potential gain. Int J Med Educ. 2017;8:37. doi:10.5116/ ijme.5869.008a

17. Hawthorne L. Circular migration of health professions - overview and critical issues. Int Labour Organ. 2014.

18. Arksey H, O'Malley L. Scoping studies: towards a methodological framework. Int J Soc Res Methodol. 2005;8(1):19-32. doi:10.1080/ 1364557032000119616

19. Levac D, Colquhoun H, O'Brien KK. Scoping studies: advancing the methodology. Implement Sci. 2010;5(1):1-9. doi:10.1186/1748-59085-69

20. Peters MDJ, Godfrey CM, Khalil H, McInerney P, Parker D, Soares CB. Guidance for conducting systematic scoping reviews. JBI Evid Implement. 2015;13(3):141-146. doi:10.1097/ XEB.0000000000000050

21. World Bank. World Bank country and lending groups. 2021. Avilable from: https://datahelpdesk.worldbank.org/knowledgebase/articles/ 906519-world-bank-country-and-lending-groups. Accessed April 11, 2021.

Journal of Multidisciplinary Healthcare

\section{Publish your work in this journal}

The Journal of Multidisciplinary Healthcare is an international, peerreviewed open-access journal that aims to represent and publish research in healthcare areas delivered by practitioners of different disciplines. This includes studies and reviews conducted by multidisciplinary teams as well as research which evaluates the results or conduct of such teams or healthcare processes in general. The journal

Submit your manuscript here: https://www.dovepress.com/journal-of-inflammation-research-journal
22. Adzei FA, Sakyi EK. Drivers of return migration of Ghanaian health professionals: perspectives from doctors and nurses in urban Ghana. Int J Migr Heal Soc Care. 2014;10(2):102-120. doi:10.1108/ IJMHSC-06-2013-0014

23. Connell J. 10.'I Never wanted to come home': skilled health workers in the south pacific. Migr Transnationalism. 2009;2:159.

24. Efendi F, Purwaningsih P, Qur'aniati N, Kurniati A, Singka E, Chen C. Return migration of Indonesian nurses from Japan: where should they go? J Nurs Educ Pract. 2013;3(8):p154-p154. doi:10.5430/jnep.v3n8p154

25. Brown. Workforce losses and return migration to the Caribbean: a case study of Jamaican nurses. Cent Migr Stud Spec Issues. 1996;13(4):197-223. doi:10.1111/j.2050-411X.1996.tb00159.x.

26. Efendi F, Nursalam N, Ulfiana E, Fauziningtyas R. Situational analysis of career choices among Indonesian nurses returnees. Indian J Public Heal Res Dev. 2019;10(2):296-299. doi:10.5958/09765506.2019.00305.X

27. Nwadiuko J, James K, Switzer GE, Stern J. Giving back: a mixed methods study of the contributions of US-based Nigerian physicians to home country health systems. Global Health. 2016;12(1):1-8. doi:10.1186/s12992-016-0165-9

28. Poppe A, Wojczewski S, Taylor K, Kutalek R, Peersman W. The views of migrant health workers living in Austria and Belgium on return migration to sub-Saharan Africa. Hum Resour Health. 2016;14 (Suppl 1):27. doi:10.1186/s12960-016-0129-4

29. Dohlman L, Dimeglio M, Hajj J, Laudanski K. Global brain drain: how can the Maslow theory of motivation improve our understanding of physician migration? Int J Environ Res Public Health. 2019;16 (7):1182. doi:10.3390/ijerph16071182

30. Mlambo M, Silén C, McGrath C. Lifelong learning and nurses' continuing professional development, a metasynthesis of the literature. BMC Nurs. 2021;20(1):1-13. doi:10.1186/s12912-021-00579-2

31. Taylor K, Blacklock C, Hayward G, et al. 'You can't stay away from your family': a qualitative study of the ongoing ties and future plans of South African health workers in the United Kingdom. Glob Health Action. 2015;8(1):26125. doi:10.3402/gha.v8.26125

32. Naicker S, Plange-Rhule J, Tutt RC, Eastwood JB. Shortage of healthcare workers in developing countries - Africa. Ethn Dis. 2009;2:19.

33. Connel J, Brown RPC, Connell J. The migration of doctors and nurses from South Pacific Island Nations. Soc Sci Med. 2004;58 (11):2193-2210. doi:10.1016/j.socscimed.2003.08.020

34. Tricco AC, Lillie E, Zarin W, O'Brien KK, Colquhoun H, Levac D, Moher D, Peters MDJ, Horsley T, Weeks L, Hempel S, Akl EA, Chang C, McGowan J, Stewart L, Hartling L, Aldcroft A, Wilson MG, Garritty C, Lewin S, Godfrey CM, Macdonald MT, Langlois EV, Soares-Weiser K, Moriarty J, Clifford T, Tunçalp Ö, Straus SE. PRISMA Extension for Scoping Reviews (PRISMA-ScR): Checklist and Explanation. Ann Intern Meds. 2018. PMID: 30178033.

covers a very wide range of areas and welcomes submissions from practitioners at all levels, from all over the world. The manuscript management system is completely online and includes a very quick and fair peer-review system. Visit http://www.dovepress.com/testimonials. php to read real quotes from published authors. 